\title{
3. 高密度エリアセンサの動向
}

\author{
正会員秋山郁 男 ${ }^{\dagger}$
}

\section{1. まえがき}

CCD (Charge Coupled Device：電荷結合素子) を はじめとする固体撮像素子, とりわけエリアセンサ は，市場規模拡大のために，よりいっそうの“低価格 化”と“多様化”が図られつつある。このうち “低価 格化” は，高密度化技術（=画素サイズ縮小化）を使 つてチップサイズを縮小化することにより達成でき る.また, 電子スチルカメラ専用 CCD やハイビジョ ン用 CCD などの高解像度エリアセンサに代表される “多様化”も，高密度化技術を使って多画素化すること により実現できる。

このように高密度化技術は，“低価格化”と“多様 化” (=多画素化)に共通する重要な技術である. 反面, 撮像素子には感光領域が狭くなると光感度が劣化する 宿命がある，すなわち，行き過ぎた高密度化は特性劣 化につながる。よって, 感度, ダイナミックレンジ, スミア等の基本性能を低下させずに，いかに“高密度 化”を図るかがこの技術の重要なポイントとなる.

\section{2. 標準方式エリアセンサの開発動向}

\section{1 高密度化の動向}

図 1 に標準方式エリアセンサの画素数の推移を示 す.同図の綐軸には, 画素数に対応させて, 目安とな る水平解像度が示されている.この 2 つの縦軸の相互 関係は一義的には決定されない. 特に単板カラーカメ ラでは, カラーフィルタ構成, 信号処理などにより， 少ない画素数で水平解像度を向上させる手法が採用さ れるからである。

エリアセンサの実用化は 20 万画素レベルから商品 化が開始され，現在では 35〜 40 万画素レベルに達し ている.標準 (NTSC) 方式では走査線数が 525 本に

† 日本電気株式会社 マイクロエレクトロニクス研究所 "Recent Trends of High-packing Density Solid State Area Sensors" by Ikuo Akiyama (Microelectronics Research Laboratories, NEC Corporation, Sagamihara)

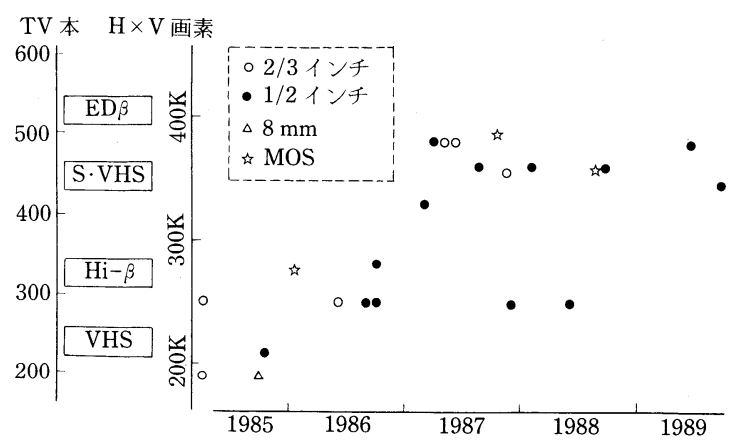

図 1 標準方式エリアセンサの画素数の推移

限定されているので, 水平解像度だけを必要以上に向 上させても画質の改善には限度がある。この限界画素 数が 40 万とも見なすことができ, 図 1 の高解像度化 の推移が飽和していることに対応している.

図 1 から読み取れるもうひとつの傾向は, イメージ サイズ (光学フォーマット) が年々減少している点で ある.すなわち, 従来の $2 / 3$ インチサイズ（イメージ エリアの対角線長 $=11 \mathrm{~mm}$ ) から $1 / 2$ インチサイズ(イ メージエリアの対角線長 $=8 \mathrm{~mm}$ ) に移行する傾向にあ る。これはチップサイズの縮小化によって歩留まりを 改善し，“低価格化”を図るのが目的である．このチ ップサイズの縮小化は, 熾烈な低価格競争が続く民生 向けエリアセンサの分野で特に顕著である．総合的な 高性能化が要求される放送局用・業務用カメラ向け工 リアセンサには $2 / 3$ インチサイズを使用し，また小型 化・低価格化が要求される民生向けエリアセンサには $1 / 2$ インチサイズを使うといった，いわゆる“棲み分 け”が進行しつつある。

さらに，1/3インチ化（イメージエリアの対角線 長 $=5.5 \mathrm{~mm}$ ) への動きもある.すでに $1 / 3$ インチ 25 万画素 $\mathrm{CCD}^{1}$ が数社より発売されている。これらセン サの画素サイズは $8.6(\mathrm{H}) \times 6.8(\mathrm{~V}) \mu \mathrm{m}$ であり，その 画素面積は後述する 1 インチ 200 万画素 CCD に匹敵 するほど小さい.

テレビジョン学会誌 Vol. 44, No. 2, pp. 116〜121 (1990) 


\section{2 標準方式 CCD の最近の技術動向}

最近の標準方式 CCD は, 既存の技術に磨きをか け，よりいっそうの “高性能化”と“多機能化”を図 る傾向にある．前者の例はフレームインタライン転送 (FIT) 構造2)や埋め込み構造フォトダイオード3)であ り, 後者は電子シャッ夕機能4) に代表される.

FIT-CCD の最近の開発例には， $2 / 3$ インチ 38 万画 素〔有効 $768(\mathrm{H}) \times 494(\mathrm{~V})$ 画素〕のもの ${ }^{5} や, 1 / 2$ イン チ 38 万画素 [有効 $775(\mathrm{H}) \times 485(\mathrm{~V})$ 画素]のもの ${ }^{6)}, 1 /$ 2 インチ 35 万画素 [有効 $712(\mathrm{H}) \times 485(\mathrm{~V})$ 画素]のも の)などがある.これらのうち, $2 / 3$ インチ FIT$\mathrm{CCD}$ は高解像度, 高 $S / N$, 低スミアが要求される放 送局用・業務用カメラに使用される。これに対し，1/ 2 インチ FIT-CCD は, 従来は放送局用・業務用専用 だった FIT 構造の民生品への展開を可能とするもの で, 家庭用カメラ一体型 VTR の高級化競争に拍車が かかるものと思われる。

FIT-CCD の最大の利点は, ここで改めて述べるま でもないが，スミアを効果的に低減できる点である。 すなわち，垂直ブランキング期間内で，垂直 CCD 中 に残存するスミア成分を高速転送によって掃き出した 後に, フォトダイオードに蓄積されていた信号電荷を 垂直 CCD 読出し, ついで, これら信号電荷をメモ リー領域へ高速転送することにより，スミアを飛躍的 に低減できる。

FIT-CCDには, 電子シャッ夕機能を比較的容易に 付加できる利点もある。すなわち, 標準方式 CCD の 通常の駆動では，等価的なシャッ夕速度が $1 / 60$ 秒と 低速なため, 動きの速い被写体に対しては画像のぼけ が生じる。これを防ぐためにはメカニカルシャッタを 使って等価的なシャッ夕速度を速くする方法も考えら れるが, FIT-CCDでは純電子的にシャッ夕速度を可 変することができる. 電子シャッ夕動作の詳細な説明 は文献) に譲るが, FIT-CCD では最大 $1 / 60$ 秒から最 小約 $1 / 2000$ 秒位までのシャッ夕速度を 1 ライン期間 (約 $1 / 15750$ 秒) 単位で任意に選択できる. 特に, 商用 周波数 $50 \mathrm{~Hz}$ の地域で, シャッ夕速度を $1 / 100$ 秒に 設定すれば，蛍光灯照明下で発生するフリッカ（蛍光 灯フリッカ) が抑制され，その効果は大きい。なお， 従来のインタライン型 CCD に簡便な電子シャッ夕機 能を付加する方法として, 擬似 (Quasi -) FIT-CCD ${ }^{9}$ が考案されたが, メモリ一領域の大きさが制限される ため, シャッ夕速度の可変範囲は $1 / 250 \sim 1 / 2000$ 秒と 比較的高速側に限られる。

埋め込み構造フォトダイオードは, 残像特性向上と 暗電流低減のために発案された ${ }^{10)}$. 図 $2(\mathrm{a})$ と ( b ) に

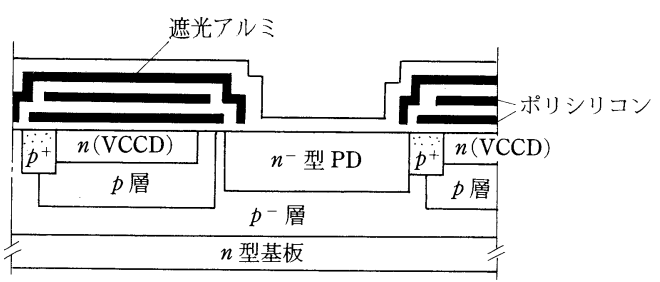

(a) 従来構造フォトダイオード

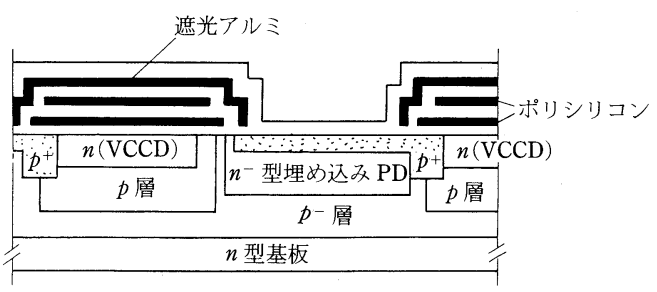

(b) 埋め込み構造フォトダイオード

図 2 フォトダイオード構造図

おのおの従来構造のフォトダイオードと埋め込み構造 フォトダイオードを示す ${ }^{11)}$. 従来構造において, 残像 特性を向上させるために, フォトダイオードから垂直 CCD への電荷転送が完全転送モードとなるようにす ると, $\mathrm{Si}_{-}-\mathrm{SiO}_{2}$ 界面が空乏化して, 暗電流が増加す る.ここで高温時の低照度撮影においては, 暗電流む らによる固定パターン雑音が支配的となるため, 感度 向上のためには暗電流の低減が不可欠である. 埋め込 み構造ではフォトダイオードの $n$ 層の上に $p^{+}$層を設 け，ここに正孔を常に蓄積することにより非空乏状態 とし, 界面準位からの暗電流の発生を防いでいる。こ の埋め込み構造フォトダイオードの採用により, 暗電 流が従来構造の $1 / 10$ 以下になったとの報告 ${ }^{7)}$ ある。

上述した電子シャッ夕機能は, 綐型オーバフロード レイン (VOD) 構造 ${ }^{12)}$ を使っても実現できる ${ }^{513114)}$ 。す なわち, 図 $3^{15)}$ に示すように, 通常動作時には基板電 圧 $V_{\text {sub }}$ を一定電圧に保って,フォトダイオードに信 号電荷を蓄積する。一方, 電子シャッ夕動作時には, 基板電圧 $V_{\text {sub }}$ に $\Delta V_{\text {sub }}$ 加えて, フォトダイオード 中に溜っていた不要電荷を $n$ 型基板へ掃き出す。こ の不要電荷の掃き出しに際しては, フォトダイオード の表面電位を一定に保つことが重要である. 埋め込み 構造フォトダイオードは, 表面が $p^{+}$層（正孔が蓄積 されている）によって常に一定電位に保たれているた め, $\mathrm{VOD}$ 構造を使った電子シャッ夕に適した構造と いえる。この電子シャッ夕の最大の特長は, インタラ イン型 CCD に FIT-CCD と同等以上に選択範囲の広 いシャッ夕機能が搭載できた点である。また, 本シャ ッ夕機能を FIT-CCDに適用した場合, 不要電荷の基 


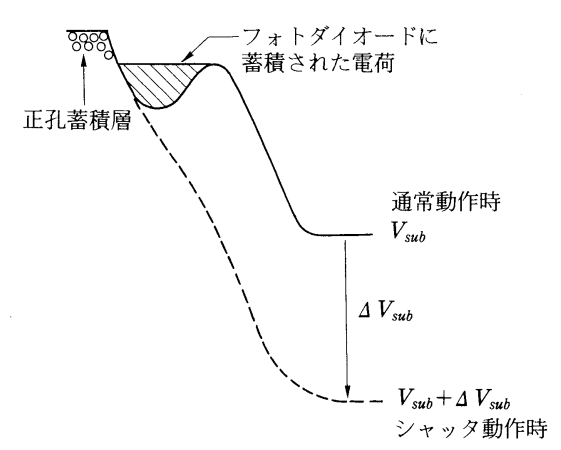

図 3 縦型オーバフロードレイン構造を用いた電子シ ヤッタ機能（フォトダイオード部の縦方向電位 分布を示す)

板への掃き出しと垂直 CCD 中に残存するスメア成分 の掃き出しとが独立して行えるため, 最小 1 ライン期 間(約 $1 / 15750$ 秒) の高速シャッタが使用可能となる ${ }^{5)}$. 反面，インタライン型 CCD に適用した場合には，垂 直 $\mathrm{CCD}$ 中に残存するスミア成分のすべてを高速掃き 出しすることができないため, CCD 自身のスミアが 充分小さいことが，本シャッ夕機能適用に当たっての 必要条件となる。

スミア低減には, 電気的な手法と素子構造自身の改 善とがある．前者には，FIT-CCDに扔けるスミア成 分の高速掃き出しがある. 一方後者には, 基板内の電 荷中性領域で発生するキャリヤの拡散を防ぐ構造, 例 えばフォトダイオード下かウェルの完全空乏化や垂 直 $\mathrm{CCD}$ の二重ウェル構造等がある。また, 遮光膜を フォトダイオードに近接させることにより, 光の漏れ 込みによるスミアが低減できる。この遮光膜とし て, 高融点材料であるタングステンシリサイド $\left(\mathrm{WSi}_{2}\right)$ を用いたものが発表されている1).

その他, 標準方式 CCD の最近のユニークな開発例 として, バーチャルフェイズを用いた $1 / 2$ インチ 36 万画素フレーム転送方式 (FT) $\mathrm{CCD}^{17)}$ と, 垂直 $\mathrm{CCD}$ にアコーディオン読出し構造を用いた $1 / 2$ インチ 40 万画素 $\mathrm{FT}-\mathrm{CCD}^{18)}$ がある.

\section{3 増幅型エリアセンサ}

増幅型エリアセンサにも高密度化の兆しが見え始め た。最近の開発例としては, $2 / 3$ インチ 25 万画素 AMI (Amplified MOS Imager) ${ }^{19)} 1 / 2$ インチ 28 万 画素 FGA（Floating Gate Array）イメージセンサ ${ }^{20)}$, 2/3 インチ 31 万画素BASIS (Base Stored Image Sensor) ${ }^{21)}$, 1/2 インチ 31 万画素 CMD (Charge Modulation Device) イメージャ ${ }^{22)}$ な゙がある.

増幅型エリアセンサは出力不均一性（固定パターン 雑音）が大きく, 今すぐに CCD と置き換え可能なレ
ベルには達していないが，半導体微細加工技術の発達 により，かなり小さく抑えられるようになってきた． 特に増幅型固体撮像素子には, 高速駆動が可能, 非破 壊読出しが可能等の, CCD にはない優れた特長があ り, 高速度カメラ ${ }^{23)}$ や画像処理用など特殊用途への応 用が期待できる ${ }^{24)}$.また，八イビジョンカメラ向けの 固体撮像素子に適しているとの見解もある.

\section{3. 超高解像度エリアセンサの開発動向}

\section{1 超高解像度化の動向}

標準方式エリアセンサに関する設計・製造技術は， 増幅型など一部のものを除いて，ほぼ確立した感があ る、今後は，よりいっそうの特性改善が進むと同時 に，用途別専用素子など “多様化”が進むであろう．

超高解像度を指向する動きは, 低速走査テレビ応用 として開始され, 100 万画素 ${ }^{25)}, 400$ 万画素 ${ }^{26)} も の$ CCD が製品化されている。しかし，これらは主に天 体観測用に開発されたものであり，数フレーム/秒程 度の準静止画を撮像することを目的としている。この ため, 30 フレーム/秒が要求されるテレビ応用（動画 撮像）には適用できない。テレビ応用を想定した超高 解像度 $\mathrm{CCD}$ は, 124 万画素 $\mathrm{CCD}^{27)}$ の開発に始まり, 電子スチルカメラ専用 $\mathrm{CCD}$ や HDTV への応用を狙 った 200 万画素レベルのものまでが試作報告されるに 至っている.

\section{2 電子スチルカメラ用エリアセンサ}

電子スチルカメラ専用 CCD の開発の兆しが現れ始 めた. 図 4 はこの一例であり, $2 / 3$ インチ 57 万画素 〔有効 $1188(\mathrm{H}) \times 484(\mathrm{~V})$ 画素〕FT-CCD ${ }^{38)}$ を示してい る.このセンサの特徵は, 電子スチル画モードと従来 のムービーモードの両方に対処すべく, 撮像領域とメ モリー領域の中間にも水平 $\mathrm{CCD}$ を設けた点である. すなわち，電子スチル画モードのときには，同図(b) に示すように, 第 1 フィールドの信号電荷を水平 CCD 1 から読出し，ついで第 2 フィールドの信号電 荷を，メモリ一領域を介して水平 CCD 2 から読出す. 一方, ムービーモードのときには, 通常の FT-CCD と同じ動作をし，信号電荷は上下のラインの信号電荷 とフィールド毎に交互に加算され，メモリ一領域を介

して水平 CCD 2 から出力される.

その他, 電子スチルカメラ専用 $\mathrm{CCD}$ として， $1 / 2$ インチ 20 万画素〔有効 $786(\mathrm{H}) \times 250(\mathrm{~V})$ 画素〕フルフ レームモード $\mathrm{CCD}^{29)} 2 / 3$ インチ 75 万画素〔有効 $766(\mathrm{H}) \times 980(\mathrm{~V})$ 画素] インタライン型 $\mathrm{CCD}^{30)}, 2 / 3$ インチ 38 万画素 [有効 $775(\mathrm{H}) \times 494(\mathrm{~V})$ 画素〕 全画素 読出し FIT- $\mathrm{CCD}^{31}$ など独創的なものが報告されてい 


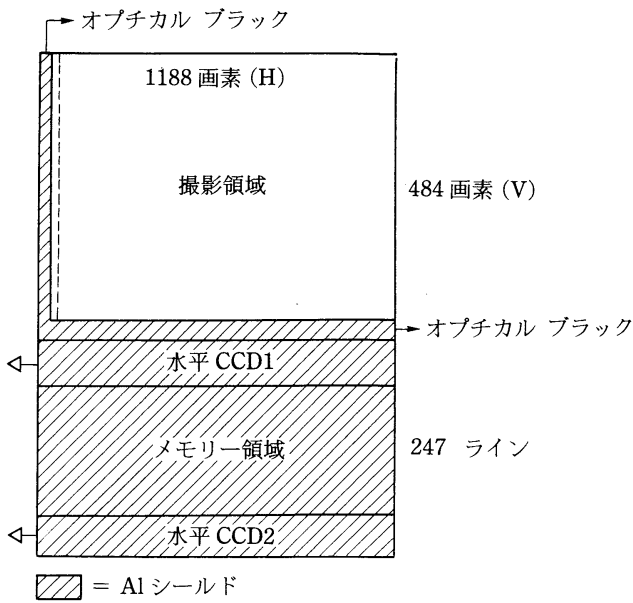

(a) 素子構成

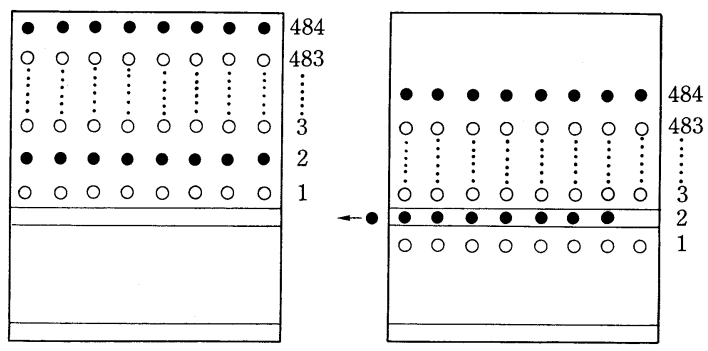

（a）信号電荷蓄積終了

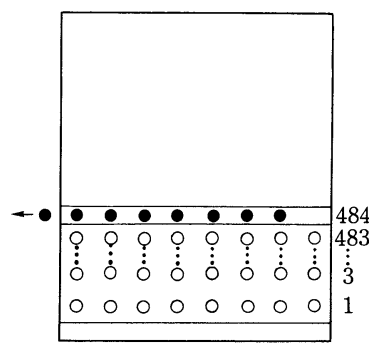

(c) 第 1 フィールドの最終 ライン読出し

（b）電子スチル画モード時の信号電荷読出し法

図 4 電子スチルカメラ専用 $\mathrm{CCD}$ の例

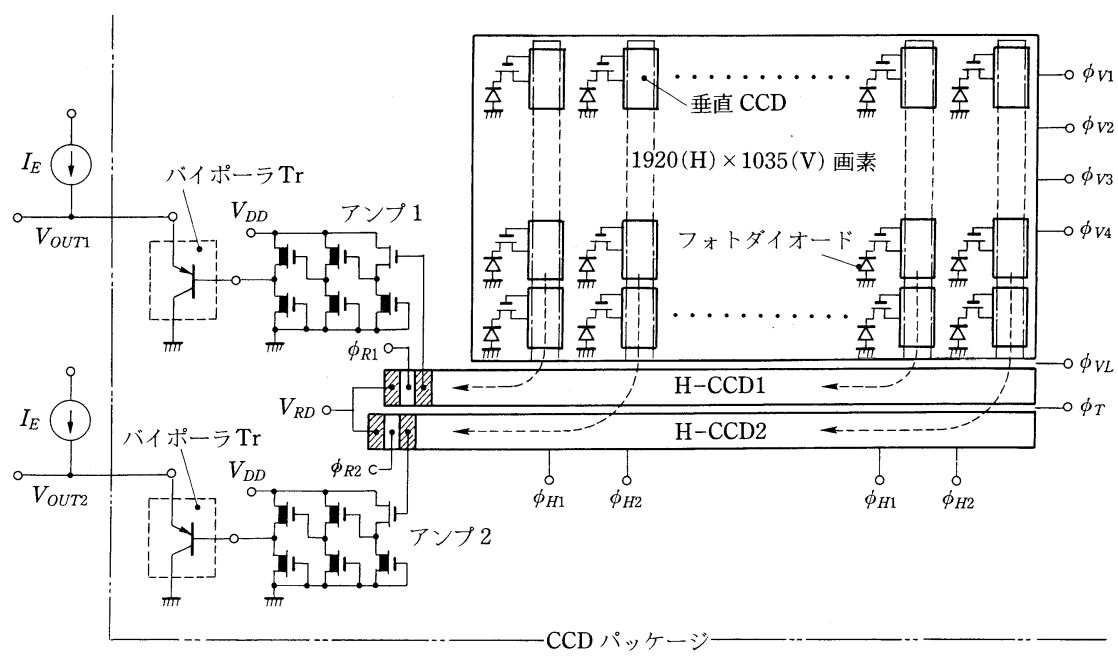

図 5200 万画素インタライン型 CCD の素子構成

る.さらに, 準静止画入力用として, $2 / 3$ インチ 140 万画素 [有効 $1320(\mathrm{H}) \times 1035(\mathrm{~V})$ 画素]フルフレームモ ード $\mathrm{CCD}^{32}$ が市販されている.

\section{3 ハイビジョン用エリアセンサ}

ハイビジョンは, 次世代テレビとして期待されてい る HDTVの一方式であり, 走査線数が標準 (NTSC) 方式の約 2 倍 (1125 本), 画面の縦横比（アスペクト
比）が $9: 16$ で, 従来よりも横長になっている.この ため, 八イビジョンカメラに塔載するエリアセンサの 画素数としては, 少なくとも 200 万画素以上が要求さ れる。八イビジョン用エリアセンサとして，いかなる 種類の固体撮像素子 (CCD, 増幅型等)を採用するか は論議の分かれるところであるが, 現在までのとこ ろ, インタライン型 $\mathrm{CCD}^{33)}$, 積層構造 $\mathrm{CCD}^{34)}$, FIT- 
$\mathrm{CCD}^{35}$ 抢よびトレンチ加工技術を使ったインタライン 型 $\mathrm{CCD}^{36)}$ が発表されており, 今後その種類はさらに 増えるものと思われる。

図 5 に 200 万画素インタライン型 $\mathrm{CCD}^{33)}$ の素子構 成を示す。イメージサイズは感度向上のためには大き い方が良いが, 歩留まり向上とフォトリソグラフィに おける露光フィールドの制限, および使用するカメラ レンズの重量・值段等からは小さい方が有利である. このため, イメージサイズは 1 インチ光学系に対応さ せて $14.0(\mathrm{H}) \times 7.8(\mathrm{~V}) \mathrm{mm}$ としている。また, 有効 画素数は $1920(\mathrm{H}) \times 1035(\mathrm{~V})$ ，画素サイズは 7.3 $(\mathrm{H}) \times 7.6(\mathrm{~V}) \mu \mathrm{m}$ であり, 現在量産されている $1 / 2$ イ ンチ 38 万画素 CCD と比較して $70 \%$ 以下に縮小され ている.

この 200 万画素 CCDを 3 個用いたハイビジョン CCD カラーカメラもすでに試作 ${ }^{37)}$ れている. 本力 メラの水平・垂直解像度は, 共に標準方式の約 2 倍の $1000 \mathrm{TV}$ 本である。感度は 2000 1x, F 4 (3200 K, 反 射率 $89.9 \%$ ）であり，また，そのときの輝度信号の $\mathrm{SN}$ 比は, 新しい $\mathrm{CCD}$ 雑音除去回路 ${ }^{38)}$ を採用するこ とにより， $30 \mathrm{MHz}$ 帯域で $52 \mathrm{~dB}$ が得られている。こ れらは従来の撮像管を用いた八イビジョンカメラに匹 敵する優れた特性である.

光電変換膜にアモルファス $\mathrm{Si}$ 膜を用いた 200 万画 素積層構造 $\mathrm{CCD}^{34)}$ の画素断面図を図 6 に示す. 通常 のインタライン型 CCD のフォトダイオードに対応す る領域は蓄積ダイオードとして機能し,アモルファス $\mathrm{Si}$ 膜の下部に形成された画素電極と結ばれている. このような構造であれば，その表面全体を受光面とし て利用でき, 光学開口率をほぼ $100 \%$ まで改善でき る、積層構造にすることにより,インタライン型 $\mathrm{CCD}$ の約 5 倍の感度向上が報告 ${ }^{34)}$ れている. 光電

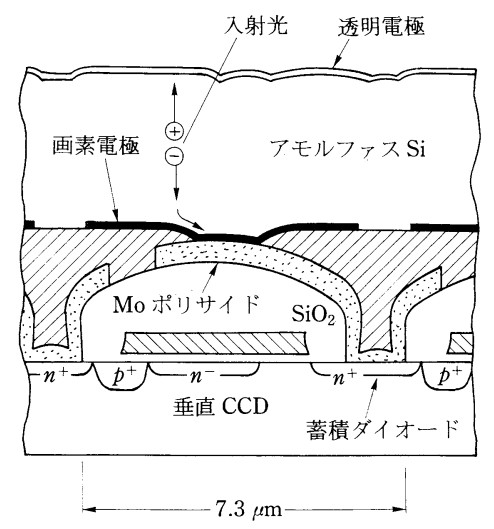

図 6200 万画素積層構造 CCD の画素断面図
変換膜の積層プロセスと半導体プロセスとの整合性, 残像の低減が課題であるといわれている。

インタライン型 CCD はチップサイズが縮小化で き, 低コスト化し易い反面, スミア特性が悪いことも 指摘されている。このスミアの低減を目的として，1 インチ 130 万画素 [有効 $1258(\mathrm{H}) \times 1035(\mathrm{~V})$ 画素] FIT $-\mathrm{CCD}^{35)}$ が開発された。1インチサイズの CCD では, チップサイズが大きくなるため, 転送電極の配線抵抗 も大きくなる，このため, 垂直 CCD 駆動パルスに波 形歪みが生じ, チップ中央部での最大転送電荷量が減 少する。この CCDでは, 図7に示すように，ポリ Si 転送電極に $\mathrm{Al}$ の裏打ち配線を施すことで配線抵抗の 低減を図っている。

トレンチ加工技術を使った $2 / 3$ インチ 200 万画素イ ンタライン型 $\mathrm{CCD}^{36}$ が提案されている. 画素断面図 を図 8 に示す. 垂直 $\mathrm{CCD}$ の転送方向に沿って長い卜 レンチ (溝)を掘り, トレンチの側壁と底面に CCD の 転送チャンネルを形成している。このため, 通常の垂

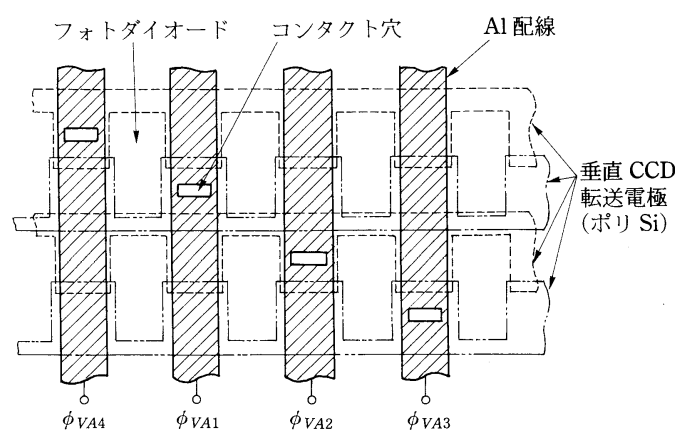

図 7 ポり $\mathrm{Si} / \mathrm{Al}$ 裏打ち配線を用いた画素部の平面図

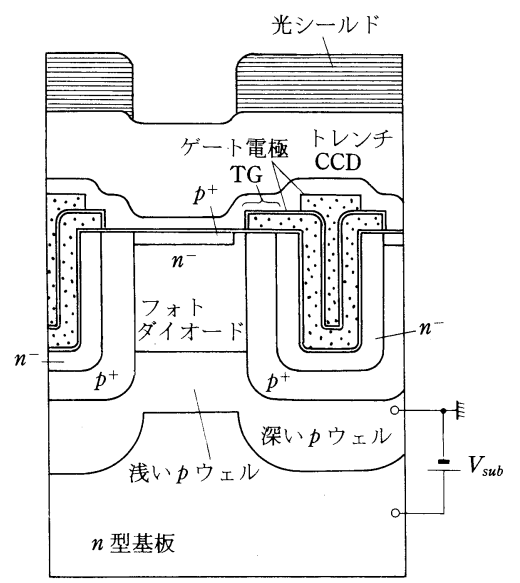

図 8 トレンチ CCD の画素断面図

テレビジョン学会誌 Vol. 44, No. 2 (1990) 
直 CCD に比べてチャンネル幅が広がり，広いダイナ ミックレンジが確保できる. 今後, 詳細な動作確認と スミアの低減対策が必要であるといわれている.

\section{4. むす び}

高密度エリアセンサを含めた固体撮像素子には，一般 的に, 光学開口率が低いためモワレが発生し易い, ナイ キスト限界内での周波数レスポンスは大きいが解像度に 伸びがない，3板式カラーカメラを構成したとき, 電気 的手法によるレジストレーション誤差の補正が難しい, 駆動のために比較的高周波のクロックパルスを使うた め, クロック雑音が飛び込み易い等の欠点がある.

反面, 長寿命でかつメンテナンスフリーなため運用 コストが安い, 図形歪みがなく, 周辺部まで空間分解 能が高い等, 上記欠点を補っても余り得る大きな利点 がある、このため, 標準方式エリアセンサはもちろん のこと, 電子スチルカメラやハイビジョンに向けての “多様化”がますます進展するものと思われる。

また昨今は, 半導体微細加工技術だけでなく, 設 計, 製造に係わる各種シミュレーション技術も進歩し ており，開発期間の短縮化と “低価格化”が期待でき る.

(1989 年 10 月 9 日受付)

\section{〔参 考 文 献〕}

1) D. L. Losee, et al.: "A $1 / 3^{\text {" }}$ Format Image Sensor with Refractory Metal Light Shield for Color Video Applications", ISSCC Dig. of Tech.Papers, pp. 90-91 (1989)

2）堀居ほか：“単板カラー撮像素子の高性能化”, テレビ全大, pp. 51-52 (1981)

3）寺西ほか：“インターライン転送方式 CCD イメージセンサ 一の残像現象”, テレビ学技報, 4, 41, pp. 25-30（Feb., 1981)

4）海瀬ほか：“電子シャッター機能付放送用 CCD カメラ”, テ レビ全大, pp. 99-100 (1986)

5）廣田ほか：“2/3 インチ有効 38 万画素 FIT-CCD 撮像素子”, テレビ全大, pp. 21-22（1989）

6) 笹野ほか：“可変電子シャッ夕付 $1 / 2$ インチ 40 万画素 CCD センサ”、テレビ学技報， $12 ， 12$, pp. 37-42（Feb. 1988）

7）渋谷ほか：“1/2 インチ 710 画素 FIT-CCD 撮像素子”, テレ ビ全大, pp. 25-26 (1989)

8）堀居ほか：“502 (V) ×600 (H) FIT-CCD 撮像素子”, テレビ 誌, 41, 11, pp. 59-66 (Nov. 1987)

9）山口ほか：“1/2 インチ $670(\mathrm{H}) \times 385(\mathrm{~V}) \mathrm{QFIT}-\mathrm{CCD}$ 撮像 素子”, テレビ全大, pp. 93-94 (1987)

10）寺西ほか：“ $p^{+} n p^{-}$構造フォトダイオードを用いた IL-CCD センサの残像特性”, テレビ全大, pp. 45-46（1981）

11）北浜ほか：“ $1 / 2$ インチ 27 万画素 $\mathrm{CCD}$ 固体撮像素子の高感 度化”，テレビ学技報，13，11，pp. 61-66（Feb. 1989）

12) Y. Ishihara, et al. : "Interline CCD Image Sensor with an Anti Blooming Structure”, ISSCC Dig. of Tech. Papers, pp. 168-169 (1982)

13）竹内ほか：“縦型オーバフロー構造 CCD イメージセンサの 駆動法一その1-”、テレビ全大, pp. 31-32（1982）

14）松井ほか：“1/2 インチ有効 38 万画素連続可変速シャッ夕付 IT-CCD 撮像素子”, テレビ全大, pp. 23-24 (1989)

15）浜崎：“高解像度 CCD 撮像素子”, 平 1 連大, pp. 3-57 3-
60 (1989)

16）秋本ほか：“IL-CCD 型固体撮像素子におけるスメアの解 析”，テレビ学技報，12，12，pp. 19-24（Feb. 1988)

17) J. Hynecek: "High-Resolution 8-mm CCD Image Sensor with Correlated Clamp Sample and Hold Charge Detection Circuit", IEEE Trans., ED-33, 6, pp. 850-362 (June 1986)

18) A. J. P. Theuwissen, et al.: "A $400 \mathrm{~K}$ Pixel $1 / 2$ " Accordion CCD-Imager", ISSCC Dig. of Tech. Papers, pp. 48-49 (1988)

19）安藤ほか：“増幅型高感度固体撮像素子 AMI”, NHK 技研 R \& D, 1, pp. 8-15 (May 1989)

20) J. Hynecek: "A New Device Architecture Suitable for High-Resolution and High-Performance Image Sensors", IEEE Trans., ED-35, 5, pp. 646-652 (May 1988)

21) N. Tanaka, et al.: "A 310 Pixel Bipolar Imager (BASIS)", ISSCC Dig. of Tech. Papers, pp. 96-97 (1989)

22）森ほか：“31 万画素 CMD イメージャ”, テレビ全大, pp.33 -34 (1989)

23）藤田ほか：“6 倍速高速度カメラシステム（アクションアナ ライザ）の開発”，テレビ全大，pp. 47-48（1989）

24) 今井：“増幅型固体撮像素子”, 平 1 連大, pp. 3-53 356 (1989)

25) R. D. McGrath, et al. : "A $1024 \times 1024$ Virtual Phase CCD Imager”, IEDM Dig. of Tech. Papers, pp. 749-750 (1983)

26) M. M. Blouke, et al.: "Large Area CCD Image Sensors for Scientific Applications", Proc. of SPIE, 570, pp. 82-88 (Aug. 1985)

27) I. Akiyama, et al.: "A $1280 \times 970$ Pixel CCD Image Sen sor”, ISSCC Dig. of Tech. Papers, pp. 96-97 (1986)

28) J. Bosiers, et al.: "A $2 / 3$ " $1188(\mathrm{H}) \times 484(\mathrm{~V})$ FrameTransfer CCD for ESP and Movie Mode", IEDM Dig. of Tech. Papers, pp. 70-73 (1988)

29）藤井ほか：“電子スチルカメラ用 CCD の技術動向”, テレビ 学技報, 13,11, pp. 55-59 (Feb. 1989)

30）武藤ほか：“2/3 インチ 80 万画素 CCD カラーイメージセン サ”，テレビ学技報, 13, 11, pp.73-78 (Feb., 1989)

31）柳井ほか：“40万画素全画素読み出し FIT-CCD”, テレビ 学技報, 13，11，pp. 79-84 (Feb. 1989)

32) E. G. Stevens, et al. : "A1. 4-Million-Element CCD Image Sensor”, ISSCC Dig. of Tech. Papers, pp. 114-115 (1987)

33）永野ほか：“200 万画素高精細度 CCD イメージセンサ”，信 学技報, ED 87-174, pp. 45-50 (Feb. 1988)

34) S. Manabe, et al.: "A 2-Million Pixel CCD Imager Overlaid with an Amorphous Silicon Photoconversion Layer", ISSCC Dig. of Tech. Papers, pp. 50-51 (1988)

35) T. Nobusada, et al.: "Frame Interline Transfer CCD Sensor for HDTV Camera”, ISSCC Dig. of Tech. Papers, pp. 88-89 (1989)

36) T. Yamada, et al.: "Trench CCD Image Sensor for High Resolution Cameras", ICCE Dig. of Tech. Papers, pp. 176 -177 (1989)

37）秋山ほか：“ハイビジョンCCD カラーカメラ”, テレビ技 報, 12, 43, pp. 37-42 (Oct. 1988)

38) M. Ohbo, et al.: "A New Noise Suppression Method for High-Definition CCD Cameras”, ICCE Dig. of Tech. Papers, pp. 178-179 (1989)

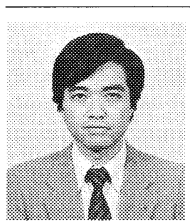

堙山ま 郁勇 昭和 52 年, 山梨大学大学院 電気工学専攻修士課程修了。同年, 日本電気 (株)に入社，中央研究所を経て，現在，同社 マイクロエレクトロニクス研究所に勤務. $\mathrm{CCD}$ ビデオ遅延線，CCD イメージセンサお よびCCDカメラの研究開発に従事. 正会 員. 